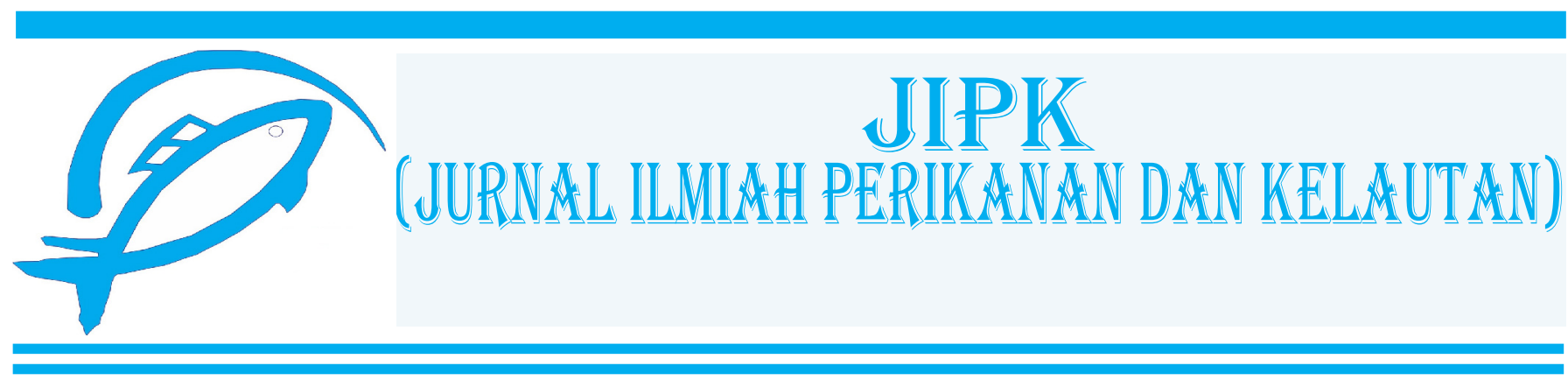

Short Communication

\title{
Characteristics of Population Growth and Mortality of Windu Shrimp (Penaeus monodon) in The Juata Water of Tarakan City, Indonesia
}

\author{
Gazali Salim ${ }^{1 *}$ (D), Kun Retno Handayani², Agus Indarjo ${ }^{3}$, Julian Ransangan ${ }^{4}$, Riky Rizky ${ }^{5}$, Lukman Yudho \\ Prakoso $^{6}$, Yen Thi Hong Pham ${ }^{7}$
}

${ }^{1}$ Department of Aquatic Resource Management, Faculty of Fisheries and Marine Science, Borneo University, Tarakan, North Kalimantan, Indonesia

${ }^{2}$ Representative of Central Java Province, Ombudsman of the Republic Indonesia.

${ }^{3}$ Department of Marine Science, Faculty of Fisheries and Marine Science, Diponegoro University Semarang, Central Java, Indonesia. ${ }^{4}$ Borneo Marine Research Institute, University Malaysia Sabah, 88400 Kota Kinabalu, Sabah, Malaysia. ${ }^{5}$ Department of Aquatic Resource Management, Faculty of Fisheries and Marine Science, Borneo University, Tarakan, North Kalimantan, Indonesia 77115

${ }^{6}$ Indonesia Defense University. IPSC Area, Sentul, Sukahati, Kec. Citeureup, Bogor, West Java, Indonesia 16810.

${ }^{7}$ Department of International Business, National Kaohsiung University of Science and Technology, Kaohsiung, Taiwan.

\section{OPEN $\bigcirc$ ACCESS \\ ARTICLE INFO \\ Received: April 25, 2020 \\ Accepted: July 05, 2020 \\ Published: March 31, 2021 \\ *) Corresponding author: \\ E-mail: axza_oke@yahoo.com}

Keywords:

Absolute growth

Mortality

Tiger prawns

Penaeus monodon

Tarakan

This is an open access article under the CC BY-NC-ND license (http://creativecommons.org/licenses/by-nc-nd/4.0/)

\section{Abstract}

The windu shrimp (Penaeus monodon) is an economically important fishery species in the waters of Tarakan. The shrimp is highly demanded for frozen seafood industry that makes its market price range attractive from Rp. 50,000 (USD 3.37) to Rp. 70,000 (USD 4.72)/kg. This can cause the species to be potentially exploited. However, due to lack of data, the exploitation status of the windu shrimp is unknown. Hence, the present study was carried out to determine the absolute growth, mortality, and exploitation level of the windu shrimp in Juata waters of Tarakan. Sampling of the shrimp using experimental trawling net was conducted four times between June and August 2020 in the waters of Tarakan. Morphometric data of the windu shrimps including sex, total length, carapace length, and total weight were recorded and analyzed. The results showed that the sex ratio of male and female tiger prawns was 1:1.08. The maximum growth of male and female shrimps was estimated at 26.875 and $21.435 \mathrm{~cm}$ respectively. The size of the male shrimps caught during the sampling ranged between 8.7 and $22.5 \mathrm{~cm}$, and was estimated to be at 13 to 67 days old respectively. Maximum growth of male shrimp was estimated at $26.875 \mathrm{~cm}$ that could be achieved within 411 days. The size of female shrimp caught during the sampling ranged from 9.8 to $19.3 \mathrm{~cm}$ with an estimated age of 21 to 87 days respectively. The maximum growth for female shrimp was estimated at $21.435 \mathrm{~cm}$, and achievable within 377 days. The mortality of male and female shrimps was not significantly different at $110.3 \%$ and $110.1 \%$ respectively. The fishing mortality for male and female shrimps was recorded at $19 \%$ and $22.5 \%$ respectively. The level of exploitation of male and female shrimps was slightly different at $17.2 \%$ and $20.5 \%$, respectively. Finally, the natural mortality for male and female shrimps was estimated at $91.3 \%$ and $87.5 \%$, respectively.

Cite this as: Salim, G., Handayani, K. R., Indarjo, A., Ransangan, J., Rizky, R.,, Prakoso, L. Y., Pham, Y. T. H. (2021). Characteristics of Population Growth and Mortality of Windu Shrimp (Penaeus monodon) in The Juata Water of Tarakan City, Indonesia. Jurnal Ilmiah Perikanan dan Kelautan, 13(1): 114-120 http://doi.org/10.20473/jipk.v13i1.21475 


\section{Introduction}

The estuarine area of Tarakan island is an important ecosystem for biological resources (Saputra et al., 2016; Perdana et al., 2016; Salim et al., 2018; Indarjo et al., 2020a). The ecosystem is known to house many economically important species including the tiger prawn or the giant tiger prawn, P. monodon (Narasimhan et al., 2013). The tiger prawn is one of the important frozen export commodities of Tarakan government. The fishing activity of windu shrimp is actively carried out in the waters around Tarakan island, particularly in the Juata waters. However, uncontrolled fishing activity of windu shrimp using unsustainable fishing gear such as trawling net can led to population degradation (Iromo et al., 2018). P. monodon can also be found in the seas of East Aceh, Java Sea, East Kalimantan, and in North Kalimantan, especially in the Sebatik waters, Nunukan. The price of the shrimp is quite high at the range of IDR 50,000 to 70,000 (US3.37-4.72) $/ \mathrm{kg}$. This has attracted fishermen to exploit windu shrimp extensively using trawling fishing method. However, according to Saputra et al., (2016), the use of trawl fishing gear is damaging due to its unselective nature. It was suggested that only trawl net with mesh size of 1.5 inches $(0.5 \mathrm{~cm})$ should be allowed to capture windu shrimps (Wahyuni et al., 2017). This is also in accordance with the regulation of the Minister of Marine Affairs and Fisheries No. 50/ KEPMEN-KP/2017.

The intense fishing activity for windu shrimp in Tarakan waters justified a sustainable fisheries management to be in place. Nevertheless, data on the basic population dynamics of the shrimp including absolute growth, mortalities, and exploitation level are currently not available. This makes sustainable fisheries management difficult. Thus, the present study was conducted with the aim to measure the basic population parameters of windu shrimp in the waters of Tarakan city. locations were determined by the use of purposive random sampling method following results of interviews with fishermen who trawled windu shrimps in the Juata waters of Tarakan Island.

\section{Materials and Methods}

\subsection{Sampling}

Field sampling of windu shrimps ( $P$. monodon) in the Juata waters of Tarakan Island was carried out for three months beginning June 2020 to August 2020. The sample collection was accomplished by using experimental trawling for 4 times (30 June 2020; 14 July 2020; 29 July 2020, and 12 August 2020) during low tide throughout the sampling period. The sampling locations were determined by the use of purposive random sampling method following results of interviews with fishermen who trawl windu shrimps in the Juata waters of Tarakan Island.

\subsection{Data collection}

Individual shrimps were randomly collected during each sampling. Then, the data which included sex, total length, carapace length, total weight of each specimen of windu shrimp were recorded at the laboratory. The data were then used to estimate the absolute growth, exploitation level, and mortalities of the windu shrimp.

\subsection{Analysis Data}

\subsubsection{Sex ratio}

At the laboratory, the male and female shrimps were separated. Then the proportions of males and females specimens were then calculated. Finally, the sex ratios were then tested using the Chi-square test (Steel and Torrie, 1993) to determine if the proportion of one sex is significantly different than the other.

$$
X^{2}=\sum \frac{(O i-e i)^{2}}{e i}
$$

Where: $\quad \mathrm{Oi}=$ frequency of tiger prawn male and female observed

ei $=$ the expectation frequency, where the frequency of tiger prawns plus females divided by two

$\chi^{2}=$ a value for the random of variable $\chi^{2}$ approaching the distribution of $\chi^{2}$

\subsubsection{Age structure}

The age structure was estimated using the formula suggested by Sparre and Venema (1999) as follows:

$$
\begin{gathered}
(\Delta \mathrm{L} / \Delta \mathrm{t})=\left(\mathrm{L}_{2}-\mathrm{L}_{1}\right) /\left(\mathrm{t}_{2}-\mathrm{t}_{1}\right) \\
\mathrm{L}_{(\mathrm{t})}=\left(\mathrm{L}_{2}+\mathrm{L}_{1}\right)
\end{gathered}
$$

Where: $\Delta \mathrm{L} / \Delta \mathrm{t}=$ Relative growth; $\Delta \mathrm{L}=$ Length of the tiger prawn; $\Delta \mathrm{t}=$ Difference of sampling time;

$\mathrm{L}_{(\mathrm{t})}=$ Modus of average length

The equation of the linear curve was obtained by plot between $\mathrm{L}_{(\mathrm{t})}$ and $(\Delta \mathrm{L} / \Delta \mathrm{t})$ value to obtain the following linear equation:

$$
\mathrm{Y}=\mathrm{a}+\mathrm{bx}
$$

Note: $\mathrm{a}=\left(\left(\sum \mathrm{y} / \mathrm{n}\right)-\left(\mathrm{b}\left(\sum \mathrm{x} / \mathrm{n}\right)\right)\right) ; \mathrm{b}=\left(\mathrm{n} \sum(\mathrm{xy})-\left(\sum \mathrm{x}\right)\left(\sum \mathrm{y}\right)\right) /$ $\left(\mathrm{n} \sum \mathrm{x}^{2}-\left(\sum \mathrm{x}\right)^{2}\right)$

The average value of modus length obtained from the regression equation was then used to calculate the asymptotic length $(L \infty)=-a / b$ and the growth coefficient is $-\mathrm{b}$. Theorical age of the shrimp when the length zero was empirically predicted following Pauly (1984) as follows:

$$
\log \left(-\mathrm{t}_{0}\right)=0.3922-0.275(\log \operatorname{L} \infty 1.038(\log \mathrm{K})
$$

Where: $\mathrm{L} \infty=$ asymptotic length $(\mathrm{cm}) ; \mathrm{K}=$ growth rate coefficient; $\mathrm{t}_{0}=$ theorical age (year) when the length is zero. 


\subsubsection{Von Bertalanffy model}

Growth equation model of the windu shrimp was derived following models suggested by Von Bertalanffy (1938), Sparre and Venema (1998), Gulland and Holt, (1959), and Sparre and Venema (1999) as follows:

$$
L t=L \infty\left(1-e^{-k(t-t)}\right)
$$

Where: $\mathrm{Lt}=$ Length with age $\mathrm{t}$ (unit of time); $\mathrm{L} \infty=$ Maximum theoretically/asymptotic length; $\mathrm{K}=$ growth coefficient growth (per unit of time); $\mathrm{t}_{0}=$ Theoretical age when the length is zero.

\subsubsection{Mortality}

Natural mortality (M) was estimated using the Pauly's empirical formula (Pauly, 1984), where:

$\log M=0,00660,279 \log L \infty+0,6543 \log K+0,4634$ $\log \mathrm{T}$

Total mortality $(Z)$ was estimated using the Beverton and Holt formula (Sparre and Venema, 1998); (Sparre and Venema, 1999) as follows:

$$
\mathrm{Z}=\mathrm{K} \cdot\left[\frac{\mathrm{L}_{\infty}-\bar{L}}{\bar{L}-L^{\prime}}\right]
$$

Capture mortality $(\mathrm{F})$ was estimated as follows:

$$
\mathrm{F}=\mathrm{Z}-\mathrm{M}
$$

The exploitation rate (E) was calculated using the Baranov formula (Sparre and Venema, 1999; Sparre and Venema, 1998) as follows:

$$
E=\left[\frac{F}{F+M}\right] \cdot\left[\frac{F}{Z}\right]
$$

Where : $\mathrm{E}=$ Rate of exploitation; $\mathrm{Z}=$ Total mortality; $\mathrm{F}$ $=$ Capture mortality; $\mathrm{M}=$ Natural mortality

\section{Results and Discussion}

\subsection{Sex Ratio and Size Distribution}

The total catch during the 4 months sampling was 589 windu shrimps which comprised of 283 males and 306 females. The sex ratio (male: female) of the windu shrimp population in the Juata waters of Tarakan City was estimated at 1: 1.08. The overall sex ratio of the windu shrimp population is almost balance between males and females. The shrimp population can be categorized into three different groups according to length and weight: small, medium and large, respectively (Table 1, Table 2, Figure 1, and Figure 2).

The predicted age structure of the windu shrimp in juata waters is depicted in Figure 3. It was noted that the growth rate of the windu shrimp decreases with length i.e. as the shrimps elongate, the growth rate becomes slower. Based on the predication (Figure 3), the average growth rate of male shrimps was $0.0264 \mathrm{~cm} /$ day and female shrimps at $0.031 \mathrm{~cm} /$ day. Based on this model, the maximum growth (infinitive) of male shrimp was $26.875 \mathrm{~cm}$, and $21.435 \mathrm{~cm}$ for female shrimps.

\begin{tabular}{|c|c|c|c|c|c|c|c|c|}
\hline \multirow{2}{*}{$\begin{array}{l}\text { Location } \\
\text { Research }\end{array}$} & \multirow{2}{*}{ Size } & \multicolumn{3}{|c|}{ Male } & \multicolumn{3}{|c|}{ Female } & \multirow{2}{*}{$\begin{array}{c}\text { Sex } \\
\text { ratio }\end{array}$} \\
\hline & & Weight & Sample & Percentage & Weight & Sample & Percentage & \\
\hline \multirow{4}{*}{$\begin{array}{c}\text { Juata } \\
\text { Waters }\end{array}$} & Small & $8.37 \pm 3.47$ & 111 & $39.22 \%$ & $7.55 \pm 2.65$ & 51 & $16.67 \%$ & $2.18: 1$ \\
\hline & Medium & $20.43 \pm 8.53$ & 168 & $59.36 \%$ & $18.16 \pm 6.26$ & 240 & $78.43 \%$ & $1: 1.43$ \\
\hline & Large & $49.84 \pm 20.84$ & 4 & $1.41 \%$ & $43.68+14.68$ & 15 & $4.90 \%$ & $1: 3.75$ \\
\hline & \multicolumn{2}{|c|}{ TOTAL } & 283 & $100 \%$ & TOTAL & 306 & $100 \%$ & 1:1.08 \\
\hline
\end{tabular}

Tabel 1. Comparison of the results of research on the total length of male and female tiger prawns

\begin{tabular}{ccccccccc}
\hline \multirow{2}{*}{$\begin{array}{c}\text { Location } \\
\text { Research }\end{array}$} & \multirow{2}{*}{ Size } & \multicolumn{3}{c}{ Male P. monodon } & \multicolumn{2}{c}{ Female P. monodon } & \multirow{2}{*}{$\begin{array}{c}\text { Sex } \\
\text { ratio }\end{array}$} \\
\cline { 2 - 9 } & & Length & Sample & Percentage & Length & Sample & Percentage & \\
\hline \multirow{3}{*}{$\begin{array}{c}\text { Juata } \\
\text { Waters }\end{array}$} & Small & $10.3 \pm 1.6$ & 110 & $38.87 \%$ & $11.0 \pm 1.2$ & 84 & $27.45 \%$ & $1.31: 1$ \\
& Medium & $14.1 \pm 2.2$ & 168 & $59.36 \%$ & $13.8 \pm 1.5$ & 193 & $63.07 \%$ & $1: 1.15$ \\
\cline { 2 - 8 } & Large & $19.4 \pm 3.1$ & 5 & $1.77 \%$ & $17.3 \pm 2.0$ & 29 & $9.48 \%$ & $1: 5.8$ \\
\hline \multicolumn{2}{c}{ TOTAL } & 283 & $100 \%$ & TOTAL & 306 & $100 \%$ & $1: 1.08$ \\
\hline
\end{tabular}

Table 2. Comparison of the results of research on the total weight of male and female tiger shrimp 

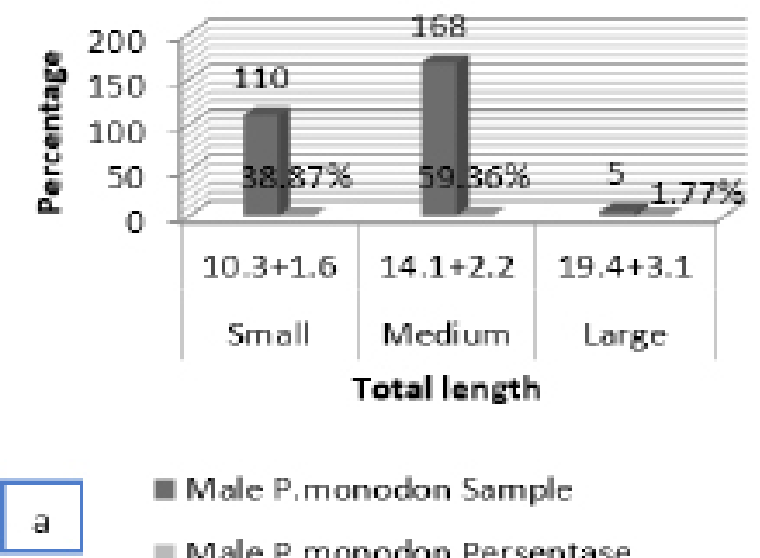

male P.monodon Persentase
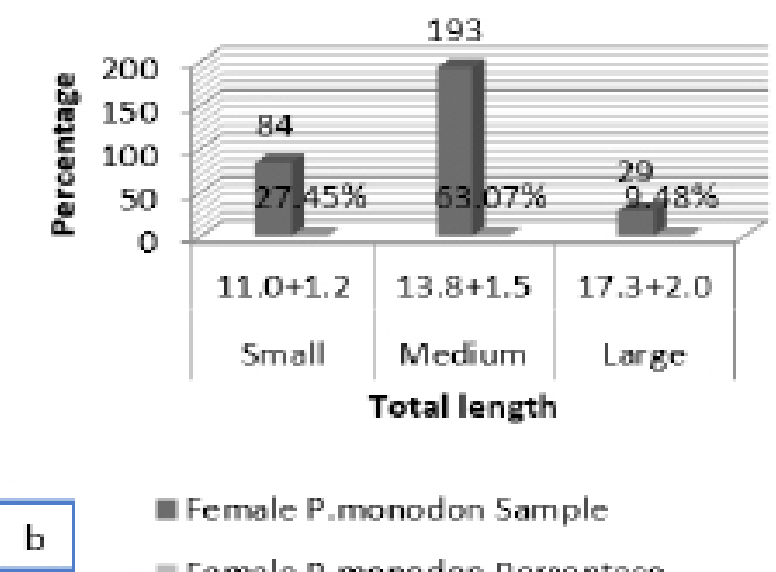

E Female P.monodon Sample

En Female P.monodon Persentase

Figure 1. Total length of male (a) and female (b) P. monodon.
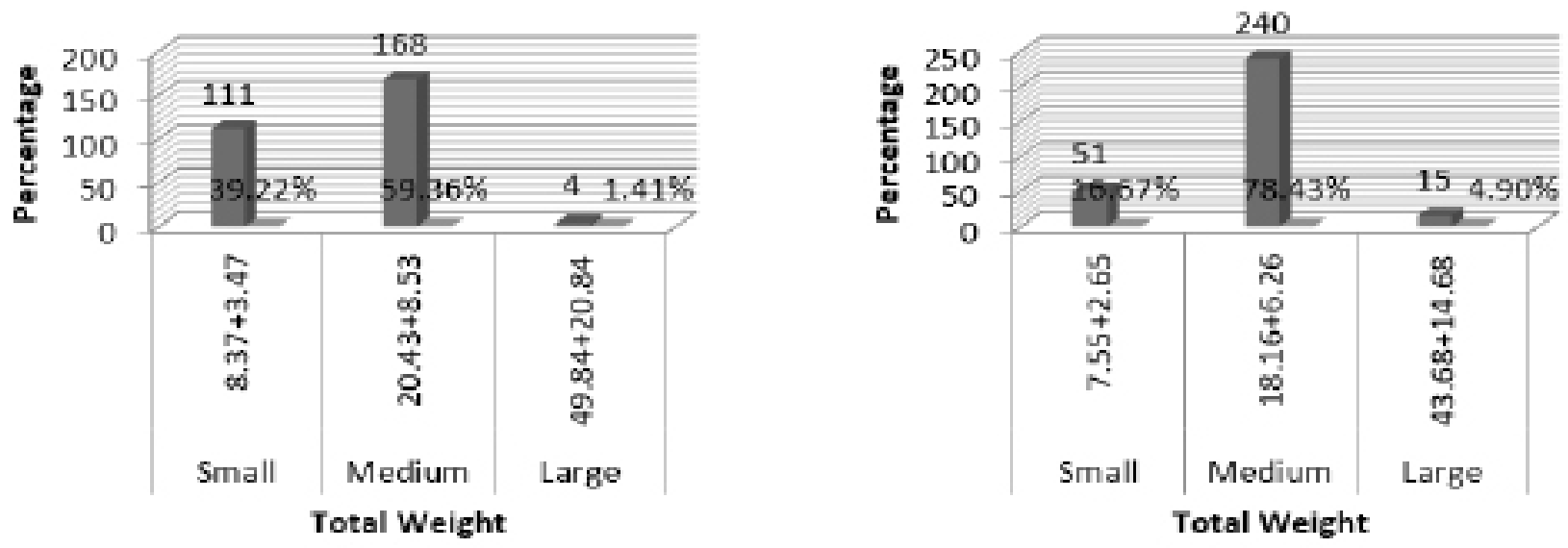

Male P.monodon Sample

- Female P.monodon Sample

a Male P.monodon Persentase

b $\quad$ Female P.monodon Persentase

Figure 2. Total weight of male (a) and female (b) $P$. monodon.
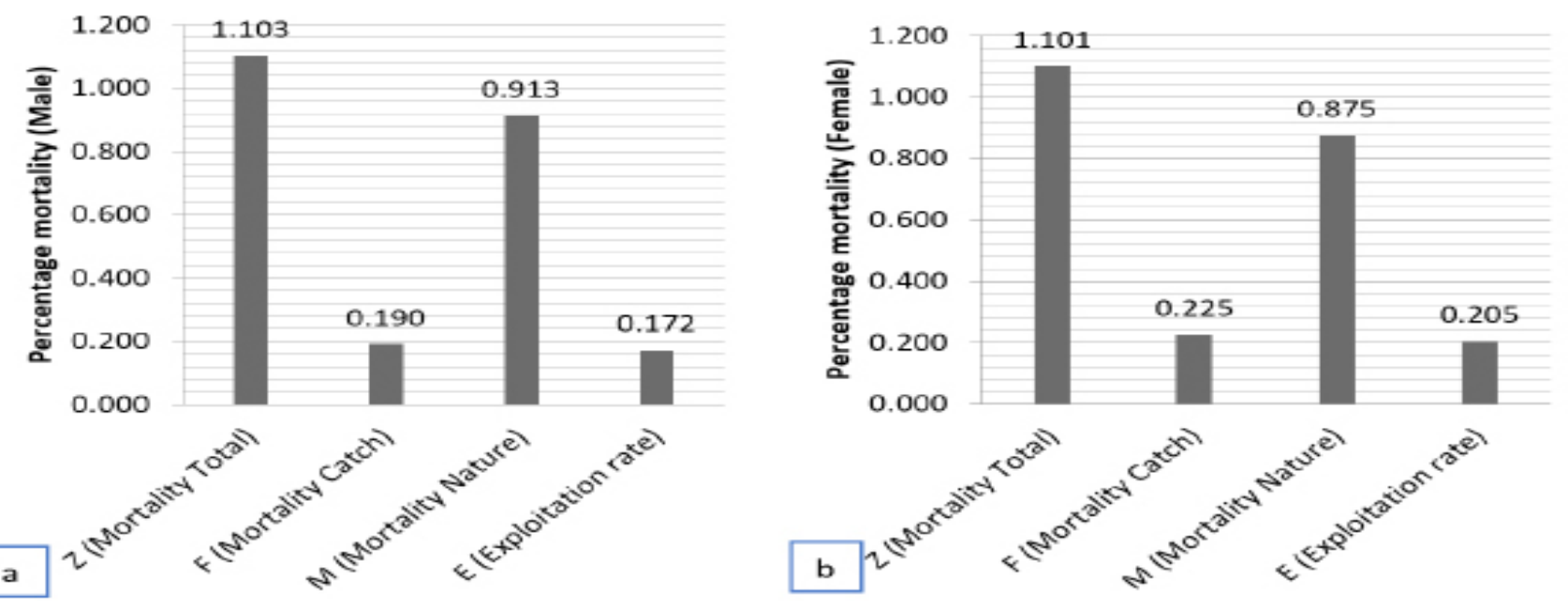

Figure 5. Mortality and exploitation rates of male and female windu shrimp in Juata waters, Tarakan. Male (a) and Female (b). 

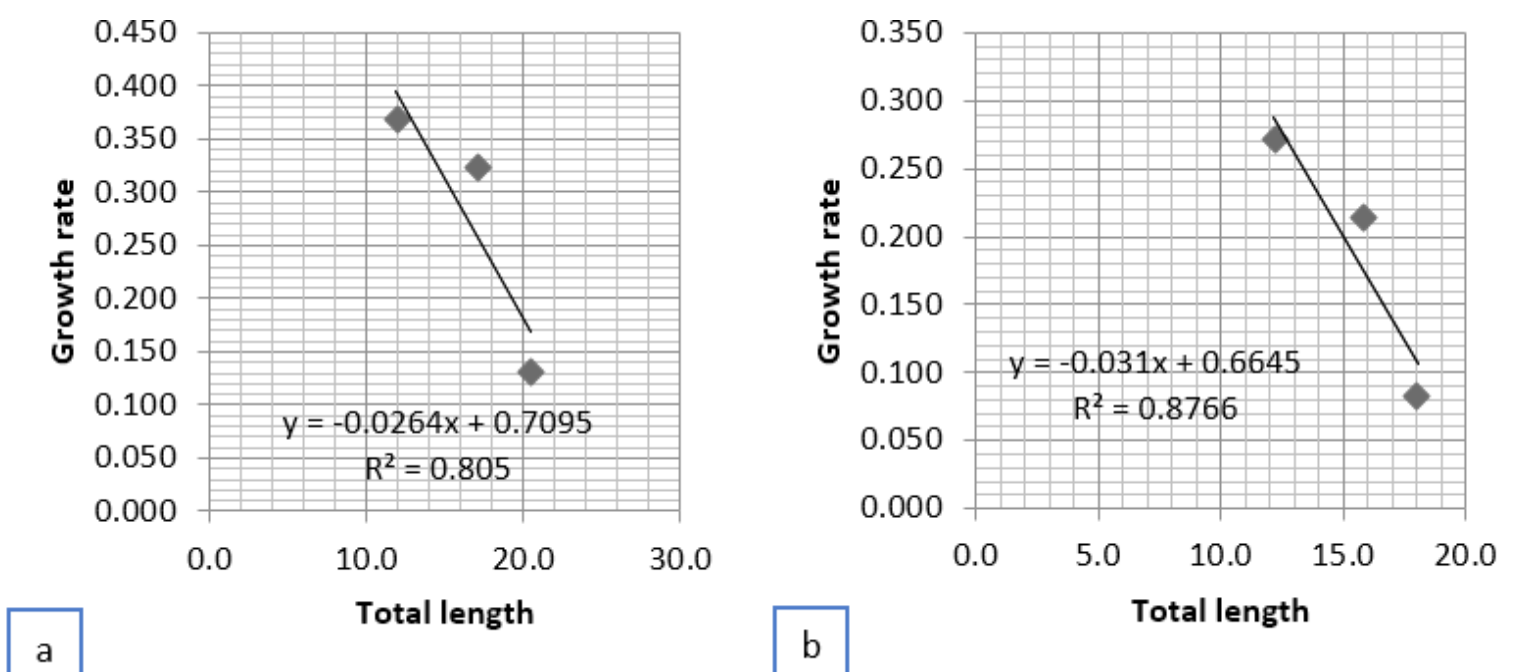

Figure 3. Predicted age structure of windu shrimp (P. monodon): Male (a) and Female (b).
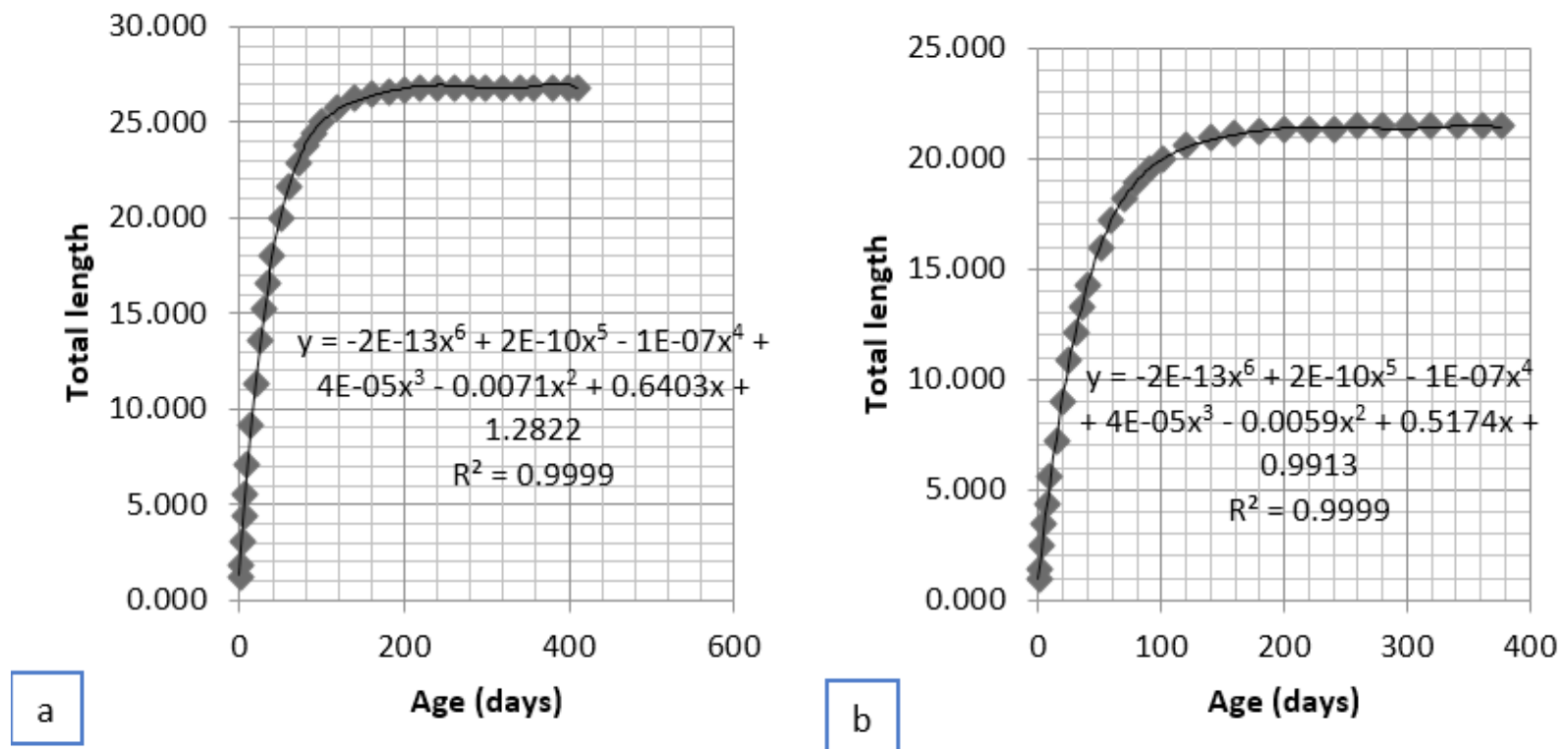

Figure 4. Von Bertalanffy model of windu shrimp (P. monodon) in Juata waters, Tarakan. Male (a) and Female (b).

\subsection{Age Structure}

In the Von Bertalanffy model, the age structure formula is based on the total length of the male tiger prawns and female tiger prawns. In the results of this study, the age structure variables for males and females (Figure 3 ), have different linear regression values. To get the regression value equation using the correlation of two different variables, namely the variable of growth speed and the variable total length of male and female tiger prawns. The variable of the age structure of male tiger prawns obtained a linear regression equation, namely y $=-0.0264 \mathrm{x}+0.7095$ with an $\mathrm{R}$ square value of 0.805 and a correlation value of 0.89722 , and the age structure of female tiger prawns obtained a linear regression equation of $y=-0.031 x+0.6645$ with the $R$ square value is 0.8766 and the correlation value is 0.93627 .

The correlation value of the two linear regression equations, both male and female, has a greater correlation value of $0.8(\mathrm{M}=0.89722$ and $\mathrm{F}=0.93627)$, according to Sarwono (2006) explaining that if the correlation value is $0.8-0.99$, it has a correlation value between the variable growth speed of tiger prawns (male and females) and the total length growth variable has a very strong relationship. This explains that the graphic image in the downward direction to meet the $\mathrm{x}$-axis (variable total male and female length), explains that the growth rate at the beginning of the growth period has a very fast growth rate, but is in line with the passage of time and 
the total length of male tiger prawns. and the female will experience slow growth until it touches the $\mathrm{x}$-axis where the growth rate is zero.

\subsection{Von Bertalanffy Growth}

Rewrite the equations, the age of the shrimp can be estimated (Effendie, 1997). For example, the smallest male shrimp captured in this study was $8.7 \mathrm{~cm}$ and the largest was $22.5 \mathrm{~cm}$. Following the Von Bertalanffy growth model derived from the data obtained in this study, the predicted age of the smallest shrimp $(8.7 \mathrm{~cm})$ was 13 days whereas the age of largest shrimp (22.5 $\mathrm{cm})$ was 67 days. As for female, the smallest shrimp recorded was at $9.8 \mathrm{~cm}$ and the largest shrimp was at $19.3 \mathrm{~cm}$. The von Bertalanffy model, predicted the age of the smallest female shrimp was 21 days and the largest shrimp was at 87 days (Figure 4).

This revealed that the windu shrimps caught by trawlers in the Juata waters of Tarakan may have not been able to reach maximum growth. The result also showed that male shrimps begin to decline in growth rate at the age of 129 days (4 months 9 days) when they reached $26.021 \mathrm{~cm}$ in length. However, based on the equation, the male shrimps needed 411 days to reach the maximum length $(26.875 \mathrm{~cm})$. As for female shrimp, it requires 377 days to reach the maximum length of $21.435 \mathrm{~cm}$ at the rate of $0.031 \mathrm{~cm} /$ day. The growth rate of female shrimp was estimated to become stagnant when the shrimp reached total length of $21.001 \mathrm{~cm}$ or at 146 days (4 months 26 days). According to Effendie (2002), young shrimps have rapid growth rate but gradually slows down as the shrimp grow older and reaches zero when the shrimp reaches autocatalytic growth. When this is reached, the shrimp will still continue to grow but in different direction which is the weight (Lagler, 1949; Indarjo et al., 2020b; Firdaus et al., 2020). The results showed that male shrimp seemed to grow faster than female shrimp. This finding agrees with the study of Hedianto et al. (2016) who found similar results of the windu shrimp in Aceh waters.

\subsection{Mortality}

The current study showed that the total annual mortality of male and female shrimp populations in the Juata waters was almost similar at $110.3 \%$ and $110.1 \%$, respectively (Figure 5). However, the female shrimps seemed to experience higher fishing mortality (22.5\%) than that of male shrimp (19\%). The exploitation rate for female shrimps was also higher (20.5\%) than male shrimps (17.2\%). According to Ningsih (2014), the fishing mortality is influenced by the exploitation rate whereby increase exploitation rate will likely to increase fishing mortality. However, due to some limitations in the predication model (Haddon et al., 2005), mortality due to fishing cannot be accurately estimated. The annual natural mortality of male shrimps was estimated at $91.3 \%$ which was far higher than female shrimps
(87.5\%). According to Sparre and Venema (1999), the natural mortality rate of a fish population can be caused by old age, exposure to diseases, natural predation, and mortality due to unsuitable environmental carrying capacity such as habitat disturbances and occurrence of extreme environmental changes or insufficient food supply (Sparre and Vename, 1999; Indarjo et al., 2020a).

\section{Conclusion}

The current study found that the ratio of male and female of the windu shrimp in the Juata waters of Tarakan was slightly biased towards female. Furthermore, the male shrimp population was noted to have greater von Bertalanffy estimated maximum length than the female shrimp. The total and natural mortalities of male shrimps were also higher than female shrimps. However, fishing and exploitation rates for female shrimps were recorded higher than male shrimps.

\section{Acknowledgement}

Researchers would like to thank the Service Institute (LPPM) of the University of Borneo Tarakan (UBT).

\section{Authors' Contributions}

Author's Contribution All authors have contributed to the final manuscript. The contribution of each author as follow, Hariyadi collected the data. All authors discussed the results and contributed to the final manuscript.

\section{Conflict of Interest}

The authors declare that they have no competing interests

\section{Funding Information}

This research was partially supported by Service Institute (LPPM) of the University of Borneo Tarakan (UBT) year 2020.

\section{References}

Effendie, M. I. (1997). Biologi Perikanan. Yogyakarta: Yayasan Pustaka Nusatama.

Firdaus, M., Salim, G., Cahyadi, J., Weliyadi, E., \& Bintoro, G. (2020). Model and nature of growth of red snapper fish Lutjanus argentimaculatus (Forsskål, 1775) fishing catch of bottom fish pots in Bunyu Waters, North Kalimantan. AACL Bioflux, 13(3): 1410-1421.

Firdaus, M., Lelono, T. D., Saleh, R., Bintoro, G., \& Salim, G. (2018). The expression of the body shape in fish species harpadon nehereus (Hamil- 
JIPK. Volume 13 No 1. April 2021 / Characteristics of Population Growth and Mortality of Windu Shrimp in....

ton, 1822) in the waters of juata laut, tarakan city, north kalimantan. AACL Bioflux, 11(3): 613-624.

Firdaus, Muhammad, \& Salim, G. (2011). Mengkaji populasi ikan puput (Ilisha elongata) yang berasal dari perairan Kota Tarakan. Harpodon, 4(1):4653.

Gulland, J. A., \& Holt, S. J. (1959). Estimation of growth parameters for data at unequal time intervals. ICES Journal of Marine Science, 25(1): 47-49. DOI: 10.1093/icesjms/25.1.47.

Haddon, M., Ziegler, P., Lyle, J., \& Burch, P. (2005). Using a spatially structured model to assess the tasmanian fishery for banded morwong (Cheilodactylus spectabilis). Fisheries Assessment and Management in Data-Limited Situations Alaska Sea Grant College Program. 20 p.

Hedianto, D., Suryandari, A., \& Tjahjo, D. (2016). Dinamika populasi dan status pemanfaatan udang windu Penaeus monodon (Fabricus, 1789) di Perairan Aceh Timur, Provinsi Aceh. Jurnal Penelitian Perikanan Indonesia, 22(2): 71-82.

Indarjo, A., Salim, G., Zein, M., Septian, D., \& Bija, S. (2020a). The population and mortality characteristics of mangrove crab (Scylla serrata) in the mangrove ecosystem of Tarakan City, Indonesia. Biodiversitas Journal of Biological Diversity, 21(8).

Indarjo, A., Salim, G., Zein, M., Soejarwo, P. A., Nugraeni, C. D., Bija, S., \& Pham, Y. T. H. (2020b). Characteristics of Von Bertalanffy growth, allometric, condition index and mortality of Periophthalmus barbarus in Mangrove and Bekantan Conservation Area (KKMB), Tarakan, North Kalimantan. Indonesian Journal of Marine Sciences/Ilmu Kelautan, 25(1) :31-38.

Iromo, H., Jabarsyah, A., \& Awaluddin. (2018). Reproduction of females mud crab (Scylla serrata) with thyroxine hormone supplementation in traditional ponds from North Borneo Indonesia. International Journal of Fish Aquatic Studies. 6: 378-381.

Lagler, K. F. (1949). Studies in freshwater fishery biology. The Progressive Fish-Culturist, 11(3): 194194.

Narasimhan, N., Maharajothi, P., Ravichelvan, R., Su kumaran, M., Ravichandran, R., \& Rengarajan, R. (2013). Biochemical studies on protein content in different tissues of selected shrimps Penaeus monodon and Penaeus vannamei. The International Journal of Pure and Applied Zoology (IJPAZ), 1(1): 92-96.

Ningsih, S. R. (2014). Kajian stok kepiting bakau (Sylla sp.) di ekosistem pesisir Kampung Gisi Desa Tembeling Kabupaten Bintan Provinsi Riau. Skripsi. Tanjung Pinang: Fakultas Ilmu Kelautan dan Perikanan, Universitas Maritim Raja Ali Haji.

Pauly, D. (1984). Fish population dynamics in tropical waters: a manual for use with programmable calculators. International Center for Living Aquatic Resources Management.

Perdana, I., Salim, G., \& Weliyadi, E. (2016). Perbandingan rasio kelamin, mortalitas dan pertumbuhan ikan nomei (Harpadon nehereus) yang berasal dari hasil penangkapan nelayan Juata Kota Tarakan. Jurnal Harpodon Borneo, 9(2): 133-142.

Saputra, N., Salim, G., \& Yulma. (2016). Analisis teknis penangkapan dan komposisi hasil tangkapan menggunakan pukat hela (trawl) di pesisir utara Tarakan. Jurnal Harpodon Borneo, 9(1): 58-70.

Sparre, P., \& Venema, S. C. (1999). Introduction to tropical fish stock assessment - Part 1. Roma: FAO Fisheries and Aquaculture Technical Paper.

Sparre, P., \& Venema, S. C. (1998). Introduction to tropical fish stock assessment. Part 1: Manual. FAO Documento Técnico de Pesca. No. 306.1 Rev. 2 (p. 434).

Steel, R. G. D., \& Torrie, J. H. (1993). Prinsip dan prosedur statistika. (Pendekatan Biometrik) (B. Sumantri, Ed.). Jakarta: Gramedia Pustaka.

Von Bertalanffy, L. (1938). A quantitative theory of organic growth (inquiries on growth laws. II). Human Biology, 10(2): 181-213.

Wahyuni, I. I., Solichin, A., \& Saputra, S. W. (2017). Beberapa aspek biologi udang putih (Penaeus indicus) di perairan sebelah utara Brebes dan Tegal, Jawa Tengah. Journal of Fisheries Science and Technology (IJFST), 13(1): 38-44. 